\title{
A Randomized, Placebo-Controlled Trial in Women of Childbearing Age to Assess the Effect of Folic Acid and Methyl-Tetrahydrofolate on Erythrocyte Folate Levels
}

Ella Schaefer*, Gregor Bieri, Ozgur Sancak, Luca Barella and Silvia Maggini

Bayer Consumer Care AG, Peter-Merian-Str. 84, 4002 Basel, Switzerland

\begin{abstract}
Objective: To evaluate the efficacy of a multi-vitamin/mineral preparation (MMP) in achieving erythrocyte folate levels (Fol-E) considered preventive of neural tube defects (NTDs).

Methods: In this single-center, double-blind, randomized, placebo (PBO)-controlled trial, healthy women of childbearing potential (WCBP) took either an oral MMP containing $400 \mu \mathrm{g}$ folic acid and $451 \mu \mathrm{g}$ L-5-methyltetrahydrofolate (MTHF) or PBO once daily for 16 weeks. Primary endpoints were achievement of Fol-E $\geq 906 \mathrm{nmol} / \mathrm{L}$ at Week 4 and maintenance of this level once achieved. Secondary efficacy variables were plasma concentrations of folate, homocysteine, and vitamins B2, B6, and B12 at Week 4, 8, 12, and 16.
\end{abstract}

Results: Of the 40 women enrolled, 20 were randomized to each study arm. All but one PBO-subject completed the study as planned. Baseline characteristics in both groups were comparable with mean Fol-E around $500 \mathrm{nmol} / \mathrm{L}$. In contrast to only one PBO-subject, all MMP subjects achieved and maintained the target Fol-E (MMP: $100 \%$ vs PBO: $5 \%, p<0.001), 14(70 \%)$ MMP subjects already by Week 4 (means \pm SD: $976 \pm 186$ vs $629 \pm 215 \mathrm{nmol} / \mathrm{L}, \mathrm{p}<0.001)$. In plasma, the only change under PBO was a $10 \%$ decrease of vitamin B12 whereas under MMP folate and vitamin B6 significantly increased and homocysteine significantly decreased. There was no serious and only one severe adverse event (AE); most common AEs were gastrointestinal with greater incidence in the MMP group (30\% versus $5 \%$ ).

Conclusion: Supplementation with folic acid and MTHF at equimolar amounts was efficacious in replenishing Fol-E of WCBP within 4 weeks to levels considered protective of NTDs.

Keywords: Folate deficiency; Neural tube defect; Folic acid; Methyltetrahydrofolate; Homocysteine

\section{Introduction}

Vitamins, minerals, and trace elements are essential nutrients as these cannot be synthesized in the human body. Requirement for such essential micronutrients is increased during pregnancy and lactation as reflected by recommendations for higher daily intakes by pregnant and lactating women worldwide [1-3]. Specifically, inadequacy of folate, a member of the B-vitamin family, is known to increase the risk of NTDs $[4,5]$. NTDs represent the second most common type of congenital malformations with an average incidence of 1-2 per 1000 live births and are associated with considerable mortality and morbidity [6,7]. To reduce the risk of NTDs a Fol-E level $\geq 906 \mathrm{nmol} / \mathrm{L}$ has been proposed $[5,6]$. This threshold can usually be achieved only by consuming food fortified with folate or by specific supplementation.

The efficacy of periconceptional folic acid supplementation in reducing the risk of NTDs is well established [8], although it might be less efficacious in women with genetic variants of methyl-tetrahydrofolate reductase (MTHFR), an enzyme required to transform folic acid into its active form MTHF [9-11]. Those women may particularly benefit from supplemental MTHF as this bypasses the metabolic activation. Another general advantage of using MTHF instead of folic acid is that it is not masking vitamin B-12 deficiency.

In this study, we aimed to evaluate the efficacy of a MMP containing equimolar amounts of folic acid and MTHF for the achievement and maintenance of Fol-E concentrations that are accepted to reduce the risk of NTDs in healthy young WCBP.

\section{Subjects and Methods}

\section{Study design}

This was a single-center, double-blind, randomized, placebocontrolled, two-arm, superiority trial in healthy WCBP in Germany.
After a screening visit, eligible subjects were randomized to either active or placebo treatment for 16 weeks. Blood samples were drawn for analysis of Fol-E and plasma folate, homocysteine and vitamins B2, B6, and B12 at baseline in intervals of 4 weeks (Week 4, 8, 12, 16). B vitamins and homocysteine are considered indirect indicators of folate status as they interact with one another via several pathways [6]. Co-primary efficacy endpoints were the percentages of (i) women achieving the target level of Fol-E $\geq 906 \mathrm{nmol} / \mathrm{L}$ at Week 4 and (ii) of women maintaining a level above this threshold after it had once been achieved. Plasma concentrations of folate, vitamin B2, B6, B12, and homocysteine were secondary efficacy endpoints. The protocol was reviewed and approved by the IEC of the "Landesärztekammer BadenWürttemberg", Stuttgart, Germany.

\section{Study population}

Eligibility criteria included healthy WCBP aged 18 to 35 years, body mass index (BMI) of $17-30 \mathrm{~kg} / \mathrm{m}^{2}$, and a normal baseline Fol-E (318 to $799 \mathrm{nmol} / \mathrm{L}$ ) [5]. Subjects had to be neither pregnant nor lactating, to use a medically acceptable form of contraception, and to sign an informed consent prior to enrolment.

*Corresponding author: Ella Schaefer, Bayer Consumer Health Medical Affairs, Nutritionals, Peter-Merian-Str. 84, 4002 Basel, Switzerland, Tel: +41582727522, E-mail: ella.schaefer@bayer.com

Received January 22, 2016; Accepted February 02, 2016; Published February 10 , 2016

Citation: Schaefer E, Bieri G, Sancak O, Barella L, Maggini S (2016) A Randomized, Placebo-Controlled Trial in Women of Childbearing Age to Assess the Effect of Folic Acid and Methyl-Tetrahydrofolate on Erythrocyte Folate Levels. Vitam Miner 5: 134

Copyright: (c) 2016 Schaefer E, et al. This is an open-access article distributed under the terms of the Creative Commons Attribution License, which permits unrestricted use, distribution, and reproduction in any medium, provided the original author and source are credited. 


\section{Study medication}

The study medication was formulated in film-coated tablets (Elevit $^{\circledR}$ film coated tablets, Bayer Health Care Consumer Care, Basel Switzerland). Tablets for active treatment contained equimolar amounts of folic acid (400 $\mu \mathrm{g}$; Caesar and Loretz GmbH, Hilden, Germany) and MTHF-Ca (451 $\mu \mathrm{g}$; Metafolin ${ }^{\circledR}$, Merck Eprova, Schaffhausen, Switzerland) as well as vitamins A (2566 IU), B1 (1.4 mg), B2 (1.4 $\mathrm{mg}), \mathrm{B} 6(1.9 \mathrm{mg}), \mathrm{B} 12(2.6 \mu \mathrm{g}), \mathrm{C}(85 \mathrm{mg}), \mathrm{D} 3$ (200 IU), E (15 IU), calcium-pantothenate $(6 \mathrm{mg})$, biotin $(30 \mu \mathrm{g})$, nicotinamide $(18 \mathrm{mg})$, calcium (125 mg), magnesium (100 mg), iron (45 mg), copper (1 mg), manganese $(2 \mathrm{mg})$, zinc $(11 \mathrm{mg})$, iodine $(220 \mu \mathrm{g})$ and selenium $(50 \mu \mathrm{g})$. Matching placebo tablets were identical in appearance but contained neither vitamins nor any of the minerals above. All subjects were instructed to take one tablet of their assigned trial medication once a day, with a glass of water during breakfast, for 16 weeks. Compliance of supplement intake was assessed by pill counting upon return of blisters at each study visit.

\section{Analytical methods}

Folate concentrations were determined in lithium heparin blood and plasma by TNO Quality of Life, Netherlands using a GLP validated microbiological assay. Fol-E was calculated according to the formula: Fol-E $=([$ whole blood folate $\times 100]$-[plasma folate $\times(100$-hematocrit $)]) /$ hematocrit [12]. Plasma homocysteine and vitamin B12 levels were measured using commercial immunoassays and plasma concentrations of vitamins B2 and B6 were determined using validated HPLC methods [13].

\section{Statistical methods}

A power calculation based on effect sizes observed in an earlier study [13] revealed 30 evaluable subjects (15 per group) to be required. Assuming a drop-out rate of $25 \%, 40$ subjects had to be randomized ( 20 per group). For statistical analysis, primary efficacy parameters (number of responders, i.e., women with a Fol-E $\geq 906 \mathrm{nmol} / \mathrm{L}$ (i) at week 4 and (ii) at any visit that did not fall below this threshold thereafter) were tested using Fisher's exact test. Secondary efficacy parameters (plasma levels of folate, vitamins B2, B6, B12 and homocysteine) were tested for temporal changes using a mixed model ANOVA appropriate for the treatment comparison of parallel groups with repeated measures of subjects over the weeks. Mixed-models were evaluated based on plots of scaled residuals vs. predicted values and Q-Q plots of scaled residuals. All tests were 2-sided at a significance level of 0.05 . Areas under the curves (AUC) were calculated using non-compartmental methods in $\mathrm{SAS}^{\circledR}$, version 9.2.

\section{Results}

Eighty female volunteers were screened for this study, 40 of whom were enrolled between 15 Feb 2010 and 5 Apr 2011. Subjects were randomized $1: 1$ to receive either active treatment $(n=20)$ or PBO $(n=20)$. One subject of the PBO group missed visit 3 and dropped out of the study (Figure 1).

On average, volunteers were 26.8 years old, had a mean BMI of $22.7 \mathrm{~kg} / \mathrm{m}^{2}$ and a Fol-E of about $500 \mathrm{nmol} / \mathrm{l}$ at baseline without any significant differences between both groups (Table 1).

\section{Efficacy}

In the active treatment group, 14 out of 20 subjects exceeded the target erythrocyte folate threshold of $906 \mathrm{nmol} / \mathrm{l}$ by week 4 as compared to 1 in 19 subjects of the placebo group ( $70 \%$ vs $5.3 \%$, Fisher's exact test $\mathrm{p}<0.0001)$. Moreover, all 20 subjects of the active treatment group showed a sustained response, i.e., Fol-E did not fall below this threshold after it once was reached, in contrast to again only one subject in the placebo group $(100 \%$ vs $5.3 \%$, Fisher's exact test $\mathrm{p}<0.0001)$. While mean folate concentrations in erythrocytes increased until the end of the treatment period, those in plasma reached a plateau at about Week 8. By contrast during treatment with placebo, mean concentrations for both remained at baseline levels throughout (Figure 2; AUCs, MMP: $138.4 \pm 18.6$ vs $\mathrm{PBO}: 70.8 \pm 23.7$ days $\mu \mathrm{mol} / \mathrm{L})$.

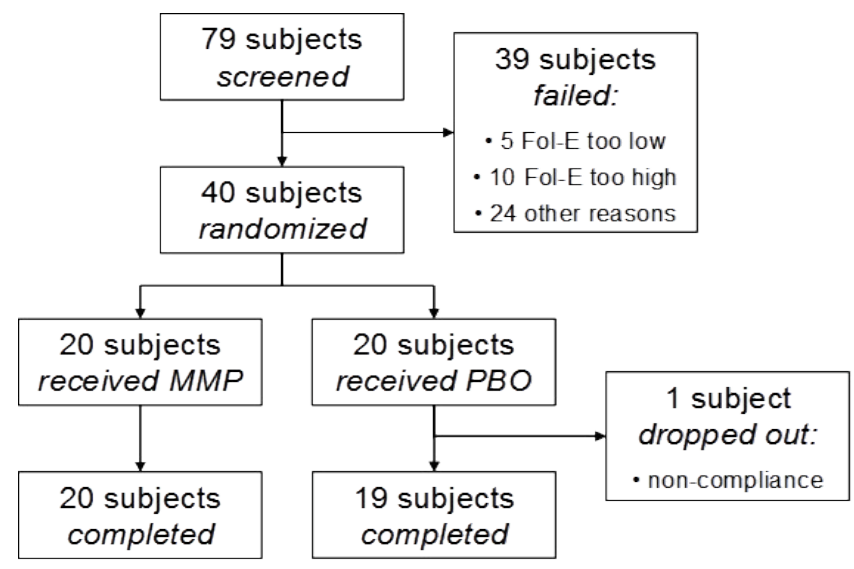

Figure 1: PConsolidated Standards of Reporting Trials (CONSORT) flow diagram
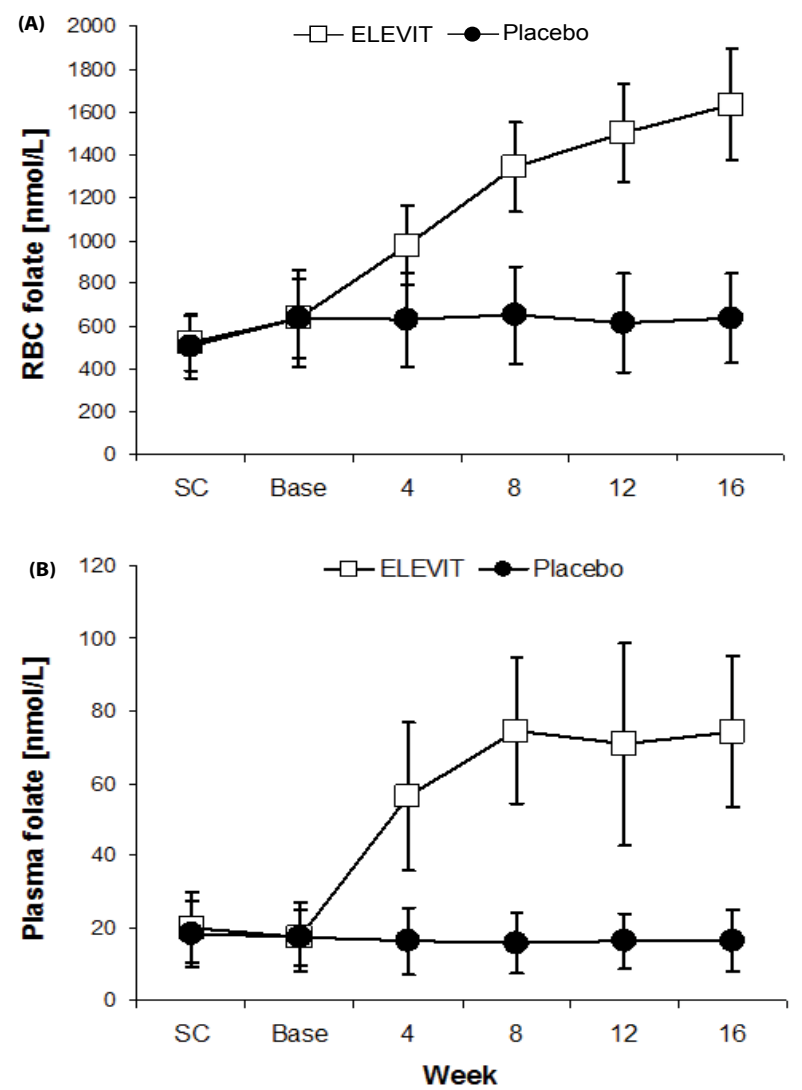

Figure 2:A and B. Folate concentrations (means \pm standard deviation) in erythrocytes (on the top) and plasma (on the bottom) during the 16 weeks of treatment.

SC: screening

$\mathrm{RBC}$ : red blood cell 
Citation: Schaefer E, Bieri G, Sancak O, Barella L, Maggini S (2016) A Randomized, Placebo-Controlled Trial in Women of Childbearing Age to Assess the Effect of Folic Acid and Methyl-Tetrahydrofolate on Erythrocyte Folate Levels. Vitam Miner 5: 134.

Page 3 of 5

Plasma levels of vitamin B6 increased similarly to those of folate in the active treatment group only, by about $50 \%$ after week 4 (Table 2; AUCs, MMP: $3.6 \pm 1.2$, PBO: $2.1 \pm 0.8$ days $\cdot \mathrm{mg} / \mathrm{L})$. By contrast, levels varied by $<10 \%$ around baseline in the $\mathrm{PBO}$ group as did plasma vitamin B2 levels in general, regardless of treatment (Table 2; AUCs, MMP: $13.1 \pm 2.0$ ), PBO: $13.4 \pm 2.1$ days.mg/L). Vitamin B12 levels either did not change under active treatment whereas they decreased by about $10 \%$ with PBO (Table 2; AUCs, MMP: $31.0 \pm 8.0$ PBO: $24.1 \pm$ 7.3 days.nmol/L). Vice versa plasma homocysteine levels decreased by about $20 \%$ already 4 weeks after initiation of treatment with MMP, and remained constant with PBO (Table 2; AUCs, MMP: $0.93 \pm 0.14$, PBO: $1.19 \pm 0.44$ days $\mathrm{mmol} / \mathrm{L})$.

\section{Safety and tolerability}

In total, there were 129 treatment-emergent AEs, of which $12(9.3 \%)$ were considered treatment-related. Eighty-seven and 42 AEs occurred in 15 (75.0\%) MMP- and 16 (80.0\%) PBO-subjects, respectively (Table $3)$. No AE was serious or led to study discontinuation, and only one was severe (vomiting), but deemed unrelated by the investigator. Most commonly affected system organ classes were infections, nervous system and gastrointestinal disorders with headache, nasopharyngitis, and nausea as most common AEs (Table 3). Gastrointestinal AEs were significantly more common with active treatment $(30.0 \%$ versus $5.0 \%$ with $\mathrm{PBO}$ ) and also more frequently considered drug-related. All but one AE (unrelated vitiligo at both hands) had resolved at the end of the study, in 24 out of the 31 subjects after using drug treatment, mainly for headache and infections.

\section{Discussion}

Since the early 1990s, there is high level evidence based on prospective controlled trials, that periconceptional folic acid

\begin{tabular}{|l|l|l|}
\hline Parameter & MMP (N=20) & PBO (N=20) \\
\hline Age (years) & $26.4 \pm 5.0(19-35)$ & $27.2 \pm 5.0(18-35)$ \\
\hline Body mass index $\left(\mathrm{kg} / \mathrm{m}^{2}\right)$ & $22.1 \pm 1.9(19-26)$ & $23.4 \pm 2.9(19-29)$ \\
\hline Erythrocyte folate $(\mathrm{nmol} / \mathrm{L})$ & $521 \pm 132(322-793)$ & $502 \pm 143(318-780)$ \\
\hline $\begin{array}{l}\text { Women consuming low amounts } \\
\text { of: }\end{array}$ & & \\
\hline - Nicotine & $6(30 \%)$ & $5(25 \%)$ \\
\hline - Xanthine & $11(55 \%)$ & $17(85 \%)$ \\
\hline - Alcohol & $13(65 \%)$ & $12(60 \%)$ \\
\hline
\end{tabular}

Table 1: Summary of baseline characteristics (means \pm standard deviation, range or $\mathrm{n}[\%])$

\begin{tabular}{|c|c|c|c|c|c|c|}
\hline \multirow[b]{2}{*}{ Vitamin } & \multirow[b]{2}{*}{ Group } & \multicolumn{5}{|l|}{ Week } \\
\hline & & 0 & 4 & 8 & 12 & 16 \\
\hline \multirow{2}{*}{$B_{2}[\mu \mathrm{g} / \mathrm{L}]$} & $\begin{array}{l}\text { MMP, } \\
N=20\end{array}$ & $121 \pm 21$ & $122 \pm 19$ & $115 \pm 27$ & $112 \pm 19$ & $115 \pm 16$ \\
\hline & $\begin{array}{l}\mathrm{PBO}, \\
\mathrm{N}=19\end{array}$ & $124 \pm 23$ & $128 \pm 27$ & $113 \pm 20$ & $114 \pm 21$ & $125 \pm 16$ \\
\hline \multirow{2}{*}{$B_{6}[\mu \mathrm{g} / \mathrm{L}]$} & $\begin{array}{l}\text { MMP, } \\
\mathrm{N}=20\end{array}$ & $\begin{array}{l}20.7 \pm \\
13.5\end{array}$ & $\begin{array}{l}34.0 \pm \\
14.1\end{array}$ & $\begin{array}{l}33.7 \pm \\
13.0\end{array}$ & $\begin{array}{l}34.8 \pm \\
12.9 \\
\end{array}$ & $\begin{array}{l}34.4 \pm \\
12.5\end{array}$ \\
\hline & $\begin{array}{l}\mathrm{PBO}, \\
\mathrm{N}=19\end{array}$ & $18.5 \pm 8.6$ & $\begin{array}{l}18.4 \pm \\
10.1\end{array}$ & $\begin{array}{l}20.4 \pm \\
10.5\end{array}$ & $17.4 \pm 8.5$ & $\begin{array}{l}19.8 \pm \\
9.5\end{array}$ \\
\hline \multirow{2}{*}{$\mathrm{B}_{12}[\mathrm{pmol} / \mathrm{L}]$} & $\begin{array}{l}\text { MMP, } \\
N=20\end{array}$ & $271 \pm 80$ & $285 \pm 72$ & $280 \pm 80$ & $273 \pm 78$ & $270 \pm 75$ \\
\hline & $\begin{array}{l}\mathrm{PBO}, \\
\mathrm{N}=19\end{array}$ & $236 \pm 90$ & $217 \pm 81$ & $203 \pm 55$ & $216 \pm 60$ & $211 \pm 67$ \\
\hline \multirow{2}{*}{$\begin{array}{l}\text { Homocysteine } \\
\text { [ } \mu \mathrm{mol} / \mathrm{L}]\end{array}$} & $\begin{array}{l}\text { MMP, } \\
N=20\end{array}$ & $10.0 \pm 1.7$ & $8.1 \pm 1.5$ & $8.0 \pm 1.1$ & $8.2 \pm 1.5$ & $8.1 \pm 1.4$ \\
\hline & $\begin{array}{l}\mathrm{PBO}, \\
\mathrm{N}=19\end{array}$ & $10.7 \pm 3.0$ & $10.5 \pm 4.7$ & $10.2 \pm 3.4$ & $10.9 \pm 4.9$ & $\begin{array}{l}10.9 \pm \\
3.3\end{array}$ \\
\hline
\end{tabular}

Table 2: Plasma concentrations of secondary efficacy parameters during the 16 weeks of treatment.

\begin{tabular}{|c|c|c|}
\hline $\begin{array}{l}\text { System Organ class } \\
\text { - Preferred term }\end{array}$ & MMP & PBO \\
\hline $\begin{array}{l}\text { Subjects, total } \\
\text { Subjects, with an adverse event }\end{array}$ & $\begin{array}{l}20(100 \%) \\
15(75 \%)\end{array}$ & $\begin{array}{l}20(100 \%) \\
16(80 \%)\end{array}$ \\
\hline Cardiac disorders & 0 & $1(5 \%)$ \\
\hline Ear and labyrinth disorders & $1(5 \%)$ & $1(5 \%)$ \\
\hline Gastrointestinal disorders & $11(55 \%)$ & $3(15 \%)$ \\
\hline - Abdominal pain & $2(10 \%)$ & $1(5 \%)$ \\
\hline - Abdominal pain upper & $3(15 \%)$ & 0 \\
\hline - Diarrhea & $4(20 \%)$ & 0 \\
\hline - Feces discolored & $2(10 \%)$ & 0 \\
\hline - Flatulence & $4(20 \%)$ & 0 \\
\hline - Nausea & $6(30 \%)$ & $1(5 \%)$ \\
\hline $\begin{array}{l}\text { General disorders and administration. site } \\
\text { conditions }\end{array}$ & $2(10 \%)$ & 0 \\
\hline - Pyrexia & $2(10 \%)$ & 0 \\
\hline Infections and infestations & $8(40 \%)$ & $7(35 \%)$ \\
\hline $\begin{array}{l}\text { Injury, poisoning and procedural } \\
\text { complications }\end{array}$ & $1(5 \%)$ & 0 \\
\hline Investigations & $2(10 \%)$ & 0 \\
\hline Metabolism and nutrition disorders & 0 & $1(5 \%)$ \\
\hline $\begin{array}{l}\text { Musculoskeletal and connective tissue } \\
\text { disorders }\end{array}$ & $1(5 \%)$ & $1(5 \%)$ \\
\hline Nervous system disorders & $8(40 \%)$ & $7(35 \%)$ \\
\hline - Dizziness & $2(10 \%)$ & $1(5 \%)$ \\
\hline - Headache & $7(35 \%)$ & $6(30 \%)$ \\
\hline Reproductive system and breast disorders & 0 & $3(15 \%)$ \\
\hline - Dysmenorrhea & 0 & $3(15 \%)$ \\
\hline $\begin{array}{l}\text { Respiratory, thoracic and mediastinal } \\
\text { disorders }\end{array}$ & $2(10 \%)$ & $1(5 \%)$ \\
\hline - Nasopharyngitis & $4(20 \%)$ & $5(25 \%)$ \\
\hline Skin and subcutaneous tissue disorders & $1(5 \%)$ & $3(15 \%)$ \\
\hline - Pruritus & 0 & $2(10 \%)$ \\
\hline
\end{tabular}

Table 3: Number of subjects (\%) with treatment-emergent adverse events by system organ class and treatment group, with preferred terms provided, if $>1$ subject affected.

supplementation decreases the incidence of NTDs [14-16]. A Fol-E threshold of $906 \mathrm{nmol} / \mathrm{L}$ has been established for WCBP to minimize the risk of NTDs [5]. Consequently, periconceptional folate supplementation has been included in international guidelines and is recommended to WCBP worldwide [6]. In some countries such as the United States, Canada, and Brazil mandatory food fortification with folic acid was implemented after which the incidence of NTDs indeed declined [17-20]. Still, periconceptional folate supplementation is the most reliable measure to meet increased requirements at conception and in the first months of pregnancy and to reduce the risk of adverse pregnancy outcomes.

Despite this evidence and the widely accepted key role of folate in early pregnancy, during screening for the study we still observed a high number of WCBP with Fol-E levels below the NTD protective 906 $\mathrm{nmol} / \mathrm{L}$ in supposedly healthy women in Germany. In 1999, about 75\% of WCBP in Germany were reported to have at least Fol-E levels $>500$ $\mathrm{nmol} / \mathrm{L}[21]$ and in another small German study comparable to ours 10 years later, $41 \%$ of women had to be excluded due to Fol-E values $>800$ $\mathrm{nmol} / \mathrm{l}[13]$. In fact, this percentage was significantly lower in our study $(13 \%)$ and about $5 \%$ were even below the general normal range for adults. We are not aware of any other study that recently investigated prevalence of folate deficiency in Germany, however, in Italy regionally $49 \%$ of WCBP and $33 \%$ of pregnant women were reported to have Fol-E levels even below normal [22]. Thus, dissemination and implementation of the WHO guidelines on achieving optimal Fol-E levels in WCBP to prevent NTDs still appear insufficient in Europe. 
In view of this epidemiological data there might be an increasing need to replenish body folate stores quickly, given the high number of unplanned pregnancies and the early neural tube closure during the first 4 weeks of pregnancy [23]. In this regard, the tested equimolar combination of folic acid and MTHF proved to be efficacious with $70 \%$ of women reaching the Fol-E target level within 4 weeks and a continuous Fol-E increase over 16 weeks. This data accords well with that for a folic acid-only preparation using the same daily dose [13] whereas studies using lower doses up to the currently recommended $400 \mu \mathrm{g} /$ day showed considerably longer periods to achieve the target level $[12,24]$. At these lower doses, folate either reached no plateau in plasma at all or it took considerably longer than the 8 weeks observed with the $800 \mu \mathrm{g}$-dose (Figure 2b), regardless of the preparation [13]. Of note, Fol-E is representative of tissue concentrations and therefore considered to more reliably reflect the maternal folate status, but plasma levels more closely vary with recent intakes and the amounts the embryo is actually exposed to [5]. In addition, plasma folate is known to inversely correlate with homocysteine of which high levels on their own have been associated with the risk of adverse pregnancy outcomes, including NTDs [25-27]. Vitamin B supplementation is known to decrease homocysteine levels, in our study to $20 \%$ lower levels by week 4. This effect size is in line with other studies and does neither appear to depend on the supplemented folate form nor the dose $[13,28]$.

Other B vitamin plasma levels at baseline were also lower than reported in the other German study evaluating a folic acid-only MMP in 2009 [13], but $>95 \%$ of our baseline values remained at least within normal ranges. Both MMPs contained the same amounts of vitamins B2, B6, and B12, i.e., $1.4 \mathrm{mg}, 1.9 \mathrm{mg}$, and $2.6 \mu \mathrm{g}$, respectively, which are more or less representing current dietary reference intakes for pregnant women in the US [29]. However, whereas in the earlier study supplementation over 16 weeks resulted in corresponding plasma level increases of $12 \%, 72 \%$, and $25 \%$, respectively, we observed a comparable increase for B6 levels only; B2 and B12 remained mostly unchanged. Whether this deviation might be linked to the use of the combination of micronutrients in the product remains open. Otherwise available data indicate both MMPs to be equivalent in their potential to increase Fol-E, although it may still warrant further investigation whether the combination provides superior benefit to women with genetic variants of MTHFR. Interestingly, in countries with mandatory folic acid fortification folate deficiency today appears to be less prevalent, however in a Brazilian study, pregnant women with the MTHFR 677TT genotype appeared to have significantly lower plasma folate levels than women with the wildtype enzyme [30].

In conclusion, the MMP containing an equimolar combination of folic acid and MTHF at daily doses of $800 \mu \mathrm{g}$ was well tolerated and proved to be efficacious in replenishing folate stores of WCBP to levels proposed to minimizing the risk of NTD within 4 weeks. The lower Fol-E values than observed in earlier studies in Germany still points at the need for improving dissemination of official recommendations to reach the target group of WCBPs.

\section{Acknowledgment}

We thank Uwe Totzke for revising the draft version of the manuscript

\section{Conflict of interest}

Authors currently are (ES, GB, SM, LB) or have been (ÖS until December 2013) full-time employees of Bayer Consumer Care, the marketing authorization holder of the tested MMP.

\section{References}

1. McPartlin J, Halligan A, Scott JM, Darling M, Weir DG (1993) Accelerated folate breakdown in pregnancy. Lancet 341: 148-149.
2. Ladipo OA (2000) Nutrition in pregnancy: mineral and vitamin supplements. Am $\mathrm{J}$ Clin Nutr 72: 280S-290S.

3. Royal Australian and New Zealand College of Obstetricians and Gynaecologists (2015) Vitamin and Mineral Supplementation and Pregnancy. C-Obs 25.

4. Crider KS, Devine O, Hao L, Dowling NF, Li S, et al. (2014) Population red blood cell folate concentrations for prevention of neural tube defects: Bayesian model. BMJ 349: g4554.

5. Daly LE, Kirke PN, Molloy A, Weir DG, Scott JM (1995) Folate levels and neural tube defects. Implications for prevention. JAMA 274: 1698-1702.

6. Cordero AM, Crider KS, Rogers LM, Cannon MJ, Berry RJ (2015) Optimal serum and red blood cell folate concentrations in women of reproductive age for prevention of neural tube defects: WHO Guideline. MMWR Morb Mortal Wkly Rep 64: 421-423.

7. Detrait ER, George TM, Etchevers HC, Gilbert JR, Vekemans M, et al. (2005) Human neural tube defects: developmental biology, epidemiology, and genetics. Neurotoxicol Teratol 27: 515-524.

8. Czeizel AE (2009) Periconceptional folic acid and multivitamin supplementation for the prevention of neural tube defects and other congenital abnormalities. Birth Defects Res A Clin Mol Teratol 85: 260-268.

9. Eskes TK (1997) Folates and the fetus. Eur J Obstet Gynecol Reprod Biol 71: 105-111.

10. Imbard A, Benoist JF, Blom HJ (2013) Neural tube defects, folic acid and methylation. Int J Environ Res Public Health 10: 4352-4389.

11. Blom HJ (2009) Folic acid, methylation and neural tube closure in humans Birth Defects Res A Clin Mol Teratol 85: 295-302.

12. Lamers Y, Prinz-Langenohl R, Bramswig S, Pietrzik K (2006) Red blood cell folate concentrations increase more after supplementation with [6S]-5methyltetrahydrofolate than with folic acid in women of childbearing age. Am J Clin Nutr 84: 156-161.

13. Bramswig S, Prinz-Langenohl R, Lamers $\mathrm{Y}$, Tobolski O, Wintergerst E, et al (2009) Supplementation with a multivitamin containing 800 microg of folic acid shortens the time to reach the preventive red blood cell folate concentration in healthy women. Int J Vitam Nutr Res 79: 61-70.

14. Czeizel AE, Dudas I (1992) Prevention of the first occurrence of neural-tube defects by periconceptional vitamin supplementation. N Engl J Med 327: 1832 1835

15. Group MVSR (1991) Prevention of neural tube defects: results of the Medical Research Council Vitamin Study. MRC Vitamin Study Research Group. Lancet 338: 131-137.

16. Smithells RW, Sheppard S, Schorah CJ, Seller MJ, Nevin NC, et al. (1980) Possible prevention of neural-tube defects by periconceptional vitamin supplementation. Lancet 1: 339-340.

17. Honein MA, Paulozzi LJ, Mathews TJ, Erickson JD, Wong LY (2001) Impact of folic acid fortification of the US food supply on the occurrence of neural tube defects. JAMA 285: 2981-2986.

18. Persad VL, Van den Hof MC, Dube JM, Zimmer P (2002) Incidence of open neural tube defects in Nova Scotia after folic acid fortification. CMAJ 167: 241245

19. Ray JG, Meier C, Vermeulen MJ, Boss S, Wyatt PR, et al. (2002) Association of neural tube defects and folic acid food fortification in Canada. Lancet 360 : 2047-2048.

20. Britto JC, Cancado R, Guerra-Shinohara EM (2014) Concentrations of blood folate in Brazilian studies prior to and after fortification of wheat and cornmeal (maize flour) with folic acid: a review. Rev Bras Hematol Hemoter 36: 275-286.

21. Thamm M, Mensink GB, Thierfelder W (1999) Folic acid intake of women in childbearing age. Gesundheitswesen 61: S207.

22. Agodi A, Barchitta M, Valenti G, Quattrocchi A, Marchese AE, et al. (2013) Dietary folate intake and blood biomarkers reveal high-risk groups in a Mediterranean population of healthy women of childbearing potential. Ann Nutr Metab 63: 179-185.

23. Eichholzer M, Tonz O, Zimmermann R (2006) Folic acid: a public-health challenge. Lancet 367: 1352-1361. 
Citation: Schaefer E, Bieri G, Sancak O, Barella L, Maggini S (2016) A Randomized, Placebo-Controlled Trial in Women of Childbearing Age to Assess the Effect of Folic Acid and Methyl-Tetrahydrofolate on Erythrocyte Folate Levels. Vitam Miner 5: 134.

24. Venn BJ, Green TJ, Moser R, McKenzie JE, Skeaff CM, et al. (2002) Increases in blood folate indices are similar in women of childbearing age supplemented with [6S]-5-methyltetrahydrofolate and folic acid. J Nutr 132: 3353-3355.

25. El-Khairy L, Vollset SE, Refsum H, Ueland PM (2003) Plasma total cysteine, pregnancy complications, and adverse pregnancy outcomes: the Hordaland Homocysteine Study. Am J Clin Nutr 77: 467-472.

26. Vollset SE, Refsum H, Irgens LM, Emblem BM, Tverdal A, et al. (2000) Plasma total homocysteine, pregnancy complications, and adverse pregnancy outcomes: the Hordaland Homocysteine study. Am J Clin Nutr 71: 962-968.
27. Mills JL, McPartlin JM, Kirke PN, Lee YJ, Conley MR, et al. (1995) Homocysteine metabolism in pregnancies complicated by neural-tube defects. Lancet 345 : 149-151.

28. Lamers Y, Prinz-Langenohl R, Moser R, Pietrzik K (2004) Supplementation with [6S]-5-methyltetrahydrofolate or folic acid equally reduces plasma total homocysteine concentrations in healthy women. Am J Clin Nutr 79: 473-478.

29. Institute of Medicine, Food and Nutrition Board (1998) Dietary reference intakes for thiamin, riboflavin, niacin, vitamin B6, folate, vitamin B12, pantothenic acid, biotin, and choline. Washington DC: National Academies Press. p: 592.

30. Barnabe A, Alessio AC, Bittar LF, de Moraes Mazetto B, Bicudo AM, et al (2015) Folate, vitamin B12 and Homocysteine status in the post-folic acid fortification era in different subgroups of the Brazilian population attended to at a public health care center. Nutr J 14: 19. 